\title{
Evaluation of The Antioxidant and Anti-Inflammatory Potential of Fermented Achyranthes japonica Nakai Extract
}

\section{Mohammad Al Mijan, Seo Hyun Park, Young Min Lee and Beong Ou Lim ${ }^{\star}$}

${ }^{1}$ Department of Integrated Biosciences, College of Biomedical and Health Science, Konkuk University, 268 Chungwondaero, Chungju-si, Chungcheongbuk-do, 27478, Republic of Korea

*Corresponding author: Beong Ou Lim; Professor, Department of Integrated Biosciences, College of Biomedical and Health Science, Konkuk University, 268 Chungwondaero, Chungju-si, Chungcheongbuk-do, 27478, Republic of Korea; Phone: +82 43-840-3570; Fax: +82 43-856-3572; E-mail: beongou@kku.ac.kr

Received: July 09, 2018; Accepted: July 30, 2018; Published: August 07, 2018

Copyright: ( 2018 Al Mijan M, et al. This is an open-access article distributed under the terms of the Creative Commons Attribution License, which permits unrestricted use, distribution, and reproduction in any medium, provided the original author and source are credited.

\begin{abstract}
Achyranthes japonica Nakai (AJ) is a medicinal plant and has well-known health benefits. This study has evaluated the antioxidant and anti-inflammatory activities of the fermented extract of AJ (FAJ). Fermentation of the extract increased the total phenolic and flavonoid contents of AJ. FAJ showed significantly higher free radical scavenging activities as compared with NFAJ. In addition, FAJ exhibited higher ferric $\left(\mathrm{Fe}^{3+}\right)$ reducing activity than NFAJ. FAJ inhibited the production of nitric oxide (NO) and prostaglandin E2 (PGE2) in lipopolysaccharide (LPS)induced RAW 264.7 cells at a higher level than NFAJ without affecting the cell viability. The mRNA expression of tumor necrosis factor a (TNF- $\alpha$ ) in RAW 264.7 cells was substantially reduced by FAJ treatment. Moreover, the upregulation of pp38 and protein kinase RNA-like endoplasmic reticulum kinase (pERK) by LPS in RAW 264.7 cells was markedly suppressed by FAJ. These results suggest that FAJ has therapeutic potential as an antioxidant and anti-inflammatory agent.
\end{abstract}

Keywords: FAJ; NFAJ; Antioxidant; Anti-inflammatory; TNF- $\alpha$; MAPK pathways

\section{Introduction}

Reactive oxygen species (ROS), consisting of radical and nonradical oxygen species, such as hydrogen peroxide $\left(\mathrm{H}_{2} \mathrm{O}_{2}\right)$, superoxide anion $\left(\mathrm{O}_{2}\right)$, and hydroxyl radical $(\cdot \mathrm{HO})$ induce damage to cellular components in human body and causes chronic illnesses [1,2]. Antioxidants, having chelating effect against free radicals, play important roles in preventing cellular oxidation and the oxidationrelated diseases [3]. While the synthetic antioxidants are known as efficient free radical scavengers, they are often associated with adverse side effects. As a consequence, antioxidants derived from natural sources are gaining attention in preventing oxidative stress-related diseases $[3,4]$.

It is well-known that oxidative stresses induce damage to the immune system and causes inflammation [5]. Inflammation is a part of the immune response that acts against pathogens and detrimental stimuli and help protect our body [6]. This response is launched as soon as immune cells detect any pathogen invasion [5,6]. After being triggered by cellular signals, macrophages accelerate the immune response by releasing pro-inflammatory cytokines and mediators in the connective tissues to fight against pathogens [7]. However, uncontrolled inflammatory response by macrophage cells can lead to chronic inflammatory diseases [8]. Previous reports indicate that LPSstimulated macrophage cells release inflammatory cytokines and mediators, including TNF- $\alpha$, nitric oxide (NO), and prostaglandin E2 $\left(\mathrm{PGE}_{2}\right)[9,10]$. Among various inflammatory pathways, mitogenactivated protein kinase (MAPK) family, which consists of p38, extracellular signal-regulated kinase (ERK), and c-Jun $\mathrm{N}$-terminal kinase (JNK), regulate the inflammation process, including the activation of inflammatory cytokines [11,12]. Synthetic steroids are generally prescribed as primary treatment for chronic inflammation; however, steroids are supposed to weaken the immune system by disrupting the cytokine network $[13,14]$. Therefore, effective natural therapeutic interventions that can target the intraplaque macrophages and their released products can be suggested for preventing inflammatory diseases.

Achyranthes japonica Nakai (AJ) has been popularly used as traditional medicine in East Asia for the treatment of chronic diseases [15]. AJ contains bioactive compounds, including inokosterone, ecdysterone, oleanolic acid, bisdesmoside and saponins, which are known to possess scavenging effects against free radicals $[16,17]$. Reports suggest that AJ extract has potent activities against inflammation and osteoarthritis owing to its bioactive compounds [15]. Fermentation is a novel process that can increment the biological activity of natural extracts through the enrichment of active compounds using bacterial strains [18]. This process has gained wide applications in food and pharmaceutical industry $[19,20]$.

Therefore, the present study was carried out to investigate the antioxidant and anti-inflammatory properties of the fermented AJ extract with the underlying mechanisms.

\section{Material and Methods}

\section{Chemicals and reagents}

Bacillus subtilis KCCM 10835P were obtained from Korea Culture Center of Microorganisms (Seoul, Korea). The antibodies for pp38, p38, ERK, pERK, JNK, and anti-pJNK, were purchased from Santa Cruz Biotech Inc. (Santa Cruz, CA, USA). Fetal bovine serum (FBS), streptomycin, trichloroacetic acid (TCA), 3-(4,5 dimethythiazol2yl)-2,5-diphenytetrazoleum (MTT), Dulbecco's Modified Eagle's medium (DMEM), and penicillin were obtained from Wako Pure Chemical Industries Ltd. (Osaka, Japan). All other chemicals and 
reagents used in this study were of analytical grade and obtained from Sigma Aldrich Inc. (St. Louis, MO, USA).

\section{Extraction and fermentation of $\mathrm{AJ}$}

Dried AJ was mechanically ground into powder form. The powder $(100 \mathrm{~g})$ was extracted three times with $75 \%$ ethanol. FAJ was fermented using a previously described method [16]. Briefly, AJ was mixed with distilled water (DW) and autoclaved at $120^{\circ} \mathrm{C}$ for $20 \mathrm{~min}$. The solution was then fermented with $5 \%$ Bacillus subtilis $\mathrm{KCCM} 10835 \mathrm{P}$ at $40^{\circ} \mathrm{C}$ for 7 days. Both fermented and non-fermented extracts were filtered through Whatman No. 1 filter paper (GE Healthcare UK Limited, Buckinghamshire, U.K.) followed by the evaporation under vacuum condition. The crude extracts of $\mathrm{AJ}$ were freeze-dried at $-80^{\circ} \mathrm{C}$ and stored at $-20^{\circ} \mathrm{C}$. The obtained yields of NFAJ and FAJ were 12.08 and $28.86 \%(w / w)$, respectively.

\section{Measurement of phenolic and flavonoid contents}

Total phenolic content was measured according to a method described earlier [21]. Each sample $(1 \mathrm{mg} / \mathrm{ml})$ and different concentrations $(0.0078-1 \mathrm{mg} / \mathrm{ml})$ of gallic acid were prepared in a 96 well-plate. An aliquot of $40 \mu \mathrm{l}$ of AJ extracts or standard were mixed with $20 \% \mathrm{Na}_{2} \mathrm{CO}_{3}(60 \mu \mathrm{l}, \mathrm{w} / \mathrm{v})$ and $1 \mathrm{M} \mathrm{FC}$ reagent $(20 \mu \mathrm{l})$ and stored in a dark place at RT for $30 \mathrm{~min}$ for reaction. The absorbance of the mixture was detected at $700 \mathrm{~nm}$ by UV- spectrophotometry (Sunrise Basic Tecan, Austria). The obtained data was expressed as standard equivalents (gallic acid (GAE)/100 g dry mass). Total flavonoid content was measured using a previously described method [22]. A volume of $25 \mu \mathrm{l}$ of AJ extracts $(1 \mathrm{mg} / \mathrm{ml})$ and catechin (standard) with different concentrations $(0.05 \mathrm{mg} / \mathrm{ml}$ to $0.5 \mathrm{mg} / \mathrm{ml})$ were mixed with DW (125 $\mu \mathrm{l})$ in 96 well-plate. $5 \% \mathrm{NaNO}_{3}(8 \mu \mathrm{l})$ was then added and the mixture was kept on a shaker for $5 \mathrm{~min}$. Then, $10 \% \mathrm{AlCl}_{3}(15 \mu \mathrm{l})$ was added to the mixture and kept with shaking for $6 \mathrm{~min}$. The reaction was stopped by adding $0.1 \mathrm{M} \mathrm{NaOH}(50 \mu \mathrm{l})$ and D.W. $(27 \mu \mathrm{l})$. After pipetting, flavonoid content was detected at $517 \mathrm{~nm}$. The calculated data was expressed as standard equivalents (catechin (CE)/100 g dry mass).

\section{DPPH radical scavenging activity}

This assay was carried out following a method mentioned earlier [23]. In this method, the hydrogen donating ability of the extract was determined based on the changing of a radical methanolic DPPH solution into non-radical form. In short, different concentrations $(0.125-4 \mathrm{mg} / \mathrm{ml})$ of AJ extracts and BHT (standard) were dissolved in DW and $\mathrm{MeOH}(100 \%)$, respectively. Then $80 \mu \mathrm{l}$ of each sample or standard solution was mixed with $80 \mu \mathrm{l}$ of $0.3 \mathrm{mM}$ DPPH solution. The mixture was then kept at RT in darkness under vigorous shaking for 30 min. Finally, the absorbance was read at $517 \mathrm{~nm}$ using a microplate reader. DPPH radical scavenging activity was calculated using the below equation:

$$
\begin{aligned}
& \text { ABTS radical scavenging activity }(\%)=\frac{1 \text {-absorbance of sample }}{\text { Absorbance of control }} \\
& \times 100
\end{aligned}
$$

\section{ABTS radical scavenging activity}

ABTS radical scavenging activity was determined using a method described earlier [24]. Initially, a $7 \mathrm{mM}$ ABTS solution was prepared in $2.5 \mathrm{mM}$ potassium and stored in darkness at RT for $16 \mathrm{~h}$ to generate $\mathrm{ABTS}$ radicals. $\mathrm{ABTS}^{+}$solution was diluted with $0.01 \mathrm{M}$ phosphate- buffered saline (PBS, $\mathrm{pH} 7.4$ ), and the absorbance was adjusted to 0.70 \pm 0.02 at $734 \mathrm{~nm}$. A volume of $300 \mu \mathrm{l}$ of AJ extracts or AA (standard) with various concentrations $(0.250-4 \mathrm{mg} / \mathrm{ml})$ were reacted with $700 \mu \mathrm{l}$ of $\mathrm{ABTS}^{+}$solution and kept at RT for 5 min for incubation. The absorbance was measured at $734 \mathrm{~nm}$. ABTS radical scavenging activity was calculated using the following formula:

ABTS radical scavenging activity $(\%)=\frac{1 \text {-absorbance of sample }}{\text { Absorbance of control }}$ $\times 100$

\section{Nitrite scavenging activity}

Nitrite scavenging activities of the samples were measured using the method of Cui et al. [25]. An aliquot of $1 \mathrm{ml}$ of diluted AJ extract $(0.250-4 \mathrm{mg} / \mathrm{ml})$ or diluted AA $(0.250-4 \mathrm{mg} / \mathrm{ml})$ were added to $1 \mathrm{mM}$ $\mathrm{NaNO}_{2}(1 \mathrm{ml})$. The mixture was added with citrate buffer $(8 \mathrm{ml}, \mathrm{pH} 3)$ and incubated at $37^{\circ} \mathrm{C}$ for $50 \mathrm{~min}$. The solution $(1 \mathrm{ml})$ was then added with acetic acid $(2 \mathrm{ml})$ and Griess reagent $(4 \mathrm{ml})$. The solution was mixed with a vortex mixer and kept at RT for $15 \mathrm{~min}$. The final solution was then detected at $520 \mathrm{~nm}$. The scavenging activity of nitrite (\%) was calculated using the following equation:

\section{Reducing power activity}

Reducing power activity was determined following a method mentioned earlier [26]. AJ extracts $(1 \mathrm{ml})$ and AA (positive control, 1 $\mathrm{ml}$ ) at different concentrations $(0.250-4 \mathrm{mg} / \mathrm{ml})$ were mixed with 0.2 $\mathrm{M} \mathrm{Na}_{3} \mathrm{PO}_{4}$ (pH 6.6) and $1 \% \mathrm{C}_{6} \mathrm{~N}_{6} \mathrm{FeK}_{3}$ and kept at $50^{\circ} \mathrm{C}$ for $30 \mathrm{~min}$. The solution was then added to $10 \%$ TCA $(2.5 \mathrm{ml})$ and centrifuged $(3,000 \mathrm{rpm})$. The supernatant $(0.25 \mathrm{ml})$ was collected and mixed with D.W. $(250 \mu \mathrm{l})$ and $0.1 \% \mathrm{FeCl}_{3}(500 \mu \mathrm{l})$. The final mixture was detected at $700 \mathrm{~nm}$.

\section{Hydroxyl radical scavenging activity}

This assay was conducted via electron spin resonance (ESR) technique (JES-FA100, JEOL Ltd., Tokyo, Japan) as described in a previous study [27]. Firstly, $10 \mathrm{mM} \mathrm{H}_{2} \mathrm{O}_{2}$ and $0.3 \mathrm{M} \mathrm{DMPO}$ were diluted using PBS buffer ( $\mathrm{pH}$ 7.4). Various concentrations (0.250-4 $\mathrm{mg} / \mathrm{ml})$ of AJ extract $(20 \mu \mathrm{l})$ or AA $(20 \mu \mathrm{l})$ was then mixed with $10 \mathrm{mM}$ $\mathrm{FeSO}_{4}(20 \mu \mathrm{l}), \mathrm{H}_{2} \mathrm{O}_{2}(20 \mu \mathrm{l})$, and DMPO $(20 \mu \mathrm{l})$. The solution was detected through JES-FA100 spectrometry (JEOL Ltd., Tokyo). The chelating effect of this assay (\%) was calculated as follows:

Hydroxyl radical scavenging activity $=[$ (peak of control-peak of sample)/peak of control] $\times 100$

\section{Superoxide radical scavenging activity}

In this method, an aliquot of $20 \mu \mathrm{l}$ of $\mathrm{AJ}$ extract $(0.250-4 \mathrm{mg} / \mathrm{ml})$ or AA $(0.250-4 \mathrm{mg} / \mathrm{ml})$ was gently added to a mixture consisted of 1.6 mM EDTA $(20 \mu \mathrm{l}), 0.8 \mathrm{M} \mathrm{DMPO}(20 \mu \mathrm{l})$, and $0.8 \mathrm{mM} \mathrm{C}_{17} \mathrm{H}_{20} \mathrm{~N}_{4} \mathrm{O}_{6}(20$ $\mu \mathrm{l})$ ). The solutions were illuminated under a UV lamp (absorbance value: $365 \mathrm{~nm}$ ) for $60 \mathrm{sec}$ before detecting with JES-FA100 spectrometry (JEOL Ltd., Tokyo).

\section{Cell viability assay}

The macrophage (RAW 264.7) cells obtained from Korean Cell Line Bank (Seoul, Korea) were seeded in a 96 well plate. After incubation for 24 hours, the cells were treated with AJ extracts $(0.250-4 \mathrm{mg} / \mathrm{ml})$ and/or LPS $(1 \mu \mathrm{g} / \mathrm{ml})$, and incubated for $18 \mathrm{~h}$. Then, MTT solution $(0.2$ 
$\mathrm{mg} / \mathrm{ml}$ ) was gently added to the plate and incubated for $4 \mathrm{~h}$. Finally, $100 \mu \mathrm{l}$ of DMSO was added to the solution and the absorbance was measured at $540 \mathrm{~nm}$ using a microplate reader (ELISA, Bio-Rad, Hercules, CA, USA).

\section{Measurement of nitric oxide}

Griess reagent method was used for the evaluation of nitric oxide (NO) production in RAW 264.7 cells [27]. Cells were seeded $\left(5 \times 10^{4}\right.$ cells/well) with DMEM medium in 96 well-plates. After $24 \mathrm{~h}$ of incubation, the cells were treated with different concentrations of $\mathrm{AJ}$ extracts $(0.250-4 \mathrm{mg} / \mathrm{ml})$ dissolved in PBS ( $\mathrm{pH} 7.4)$ with or without LPS $(1 \mu \mathrm{g} / \mathrm{ml})$ for $18 \mathrm{~h}$. Then, $80 \mu \mathrm{l}$ of cultured medium was mixed with $80 \mu \mathrm{l}$ of Griess reagent and kept for incubation at RT in darkness under continuous shaking for $10 \mathrm{~min}$. The absorbance was measured at $540 \mathrm{~nm}$ using a microplate reader. The concentration of NO was determined by comparing with a sodium nitrite $\left(\mathrm{NaNO}_{2}\right)$ standard curve.

\section{Measurement of $\mathrm{PGE}_{2}$ production}

The macrophage cells were seeded $\left(1 \times 10^{6}\right.$ cells $\left./ \mathrm{ml}\right)$ and treated (or untreated) with AJ extracts at various concentrations $(0.500-4 \mathrm{mg} / \mathrm{ml})$ for $30 \mathrm{~min}$. After incubation, $1 \mu \mathrm{g} / \mathrm{ml}$ of LPS was added to the cultured media. After centrifugation at 5,000 $\times \mathrm{g}$ for $10 \mathrm{~min}$, the supernatant was collected and the $\mathrm{PGE}_{2}$ production in the cells was measured by an assay kit (Cayman Chemical, Ann Arbor, MI, USA).

\section{Reverse-transcriptase polymerase chain reaction (RT-PCR) assay}

Total RNA was isolated from macrophage cells using Trizol reagent (Life Technologies, CA, USA). Complementary DNA (cDNA) was reverse-transcribed using oligo (dT12-18, $0.5 \mu \mathrm{g} / \mu \mathrm{l})$, MuLV reverse transcriptase, and $1 \mathrm{mM}$ deoxyribonucleotide triphosphate (dNTP). The sequences of the primers were designed as follows: TNF- $\alpha$ : $5^{\prime}-$ AGCACAGAAAGCATGATCCG-3' CTGATGAGAGGGAGGCCATT-3'; GCAAAGTGGAGATTGTTGCCATC-3' and GAPDH: and CATATTCTCGTGGTTCACACCC-3. PCR products were electrophoresed in an agarose gel (2\%) stained with ethidium bromide. The quantification of the change of mRNA levels was performed using an Image J 1.46 software (NIH, Bethesda, MD, USA).

\section{Western blot assay}

The LPS-induced RAW 264.7 cells were treated with AJ extracts (1-4 $\mathrm{mg} / \mathrm{ml}$ ). Nuclear and cytoplasmic protein extraction was carried out according to the manual of NE-PER kit (Pierce Biotechnology, Rockford, IL, USA). Protein concentration of the supernatant was determined using Bradford reagent (Bio-Rad, Hercules, CA, USA). SDS-polyacrylamide gel electrophoresis was performed to separate and transfer the protein $(50 \mu \mathrm{g})$ into a nitrocellulose membrane (Millipore, Billerica, MA, USA). The membrane was blocked using TBST solution and kept in diluted primary rabbit antibodies (1:1000) for 24 hours. After washing with TBST solution, the membrane was incubated with secondary rabbit antibodies (1:2000) at RT for $1 \mathrm{~h}$. The immunodetection was enhanced using a chemiluminescent substrate (ECL, SurModics, MN, USA) and the immunosignals were captured by LAS-3000 system (Fuji Photo Film Co., Ltd., Japan). The intensity of the protein expression levels were analysed by Image J 1.46 software (NIH, Bethesda, MD, USA).

\section{Statistical analysis}

The obtained data were represented as mean \pm standard deviation (S.D, n=3). All data were analysed using GraphPad Prism 5 (GraphPad software, Inc., La Jolla, CA) and Microsoft Excel 2010. The statistical significant was set at $\mathrm{P}<0.05$ and the analyses were carried out using one-way analysis of variance (ANOVA).

\section{Results}

\section{Total phenolic and flavonoid contents}

Polyphenols found in plant extracts have numerous bioactive functions [28]. Total phenolic contents of NFAJ and FAJ were $2.52 \mathrm{mg}$ and $5.75 \mathrm{mg}$ GAE per $100 \mathrm{~g}$ of dry mass, respectively (data not shown). The flavonoid contents of NFAJ and FAJ were 2.27 and $3.56 \mathrm{~g} \mathrm{CE}$ per $100 \mathrm{~g}$ dry mass, respectively (data not shown). Interestingly, phenolic content in FAJ were twofold higher than NFAJ. The content of flavonoid was also significantly higher in FAJ compared to NFAJ.

\section{Free radical scavenging activities of AJ extracts}

Antioxidants scavenge free radicals, such as DPPH and ABTS by donating hydrogen. AJ extracts showed concentration-dependent scavenging activities against DPPH, ABTS, and nitrite radicals. DPPH radical scavenging activities of NFAJ and FAJ were $9.84-58.43 \%$ and $33.15-87.16 \%$, respectively at the concentration of $0.125-4 \mathrm{mg} / \mathrm{ml}$ (Table 1). The inhibitory effect of NFAJ (36.31\%) against DPPH was significantly lower than the positive control $(95.36 \%)$, whereas the effect of FAJ (86.33\%) was close to that of the positive control at 2 $\mathrm{mg} / \mathrm{ml}$ concentration level. In addition, the half maximal inhibitory concentration $\left(\mathrm{IC}_{50}\right)$ of $\mathrm{FAJ}(0.36 \mathrm{mg} / \mathrm{ml})$ was significantly lower than NFAJ $(3.02 \mathrm{mg} / \mathrm{ml})$. Similarly, ABTS radical scavenging activity of FAJ $(75.04 \%)$ was significantly $\left({ }^{\star} \mathrm{P}<0.05\right)$ higher than NFAJ $(49.24 \%)$ at 2 $\mathrm{mg} / \mathrm{ml}$ of concentration. Moreover, the IC50 value of FAJ (1.49) was lower than NFAJ (2.19). Nitrite scavenging activity was also remarkably higher in FAJ $(37.33 \%)$ than NFAJ $(21.76 \%)$. The IC50 values of NFAJ and FAJ were 4.19 and $3.07 \mathrm{mg} / \mathrm{ml}$, respectively.

\section{Reducing power, hydroxyl and superoxide radical scavenging activities of $\mathrm{AJ}$ extracts}

Reducing power activity, which determines the electron donating ability of the extracts, is shown in Figure 1A. Both NFAJ and FAJ showed concentration-dependent Fe (III)-reducing activities, and the activities of FAJ $(0.10-1.18 \mathrm{~nm})$ was higher than NFAJ $(0.09-0.58 \mathrm{~nm})$ at $0.125-4 \mathrm{mg} / \mathrm{ml}$ concentration. The $\mathrm{EC}_{50}$ values of NFAJ and FAJ, which measure the concentration at which $50 \%$ of the maximum effect is produced, were 1.66 and $0.59 \pm 0.05 \mathrm{mg} / \mathrm{ml}$, respectively (Table 1). The scavenging activities of the extracts against hydroxyl radical $(\bullet \mathrm{HO})$ are shown in Figure 1B. The results indicate that the hydroxyl radical scavenging activities of NFAJ and FAJ were dose-dependently increased, and FAJ (11.24-79.13\%) demonstrated higher efficiency than NFAJ (14.23-48.14\%) at $0.25-4 \mathrm{mg} / \mathrm{ml}$ concentration level. AJ extracts exhibited $\mathrm{O}_{2}^{-}$scavenging effects, which ranged between 6.80 and $43.19 \%$, and 9.30 and $48.63 \%$ for NFAJ and FAJ, respectively at $0.25-4$ $\mathrm{mg} / \mathrm{ml}$ concentration (Figure $1 \mathrm{C}$ ). The above results suggest that the fermentation of AJ extract resulted in a significant increase in antioxidant activities. 
Citation: $\quad$ Al Mijan M, Hyun Park S, Min Lee Y and Ou Lim B* (2018) Evaluation of The Antioxidant and Anti-Inflammatory Potential of Fermented Achyranthes japonica Nakai Extract. Nat Prod Chem Res 6: 337. doi:10.4172/2329-6836.1000337

Page 4 of 7

\begin{tabular}{|c|c|c|c|c|c|c|c|}
\hline \multirow[b]{2}{*}{ Extract } & \multicolumn{2}{|l|}{ DPPH radical } & \multicolumn{2}{|l|}{ ABTS $^{+}$radical } & \multicolumn{2}{|l|}{ Nitrite radical } & \multirow{2}{*}{$\begin{array}{l}\text { Reducing power } \\
{ }^{+\dagger} \mathrm{EC}_{50} \text { value } \\
(\mathrm{mg} / \mathrm{ml})\end{array}$} \\
\hline & $\begin{array}{l}\text { Chelating activity (\%) } \\
(2 \mathrm{mg} / \mathrm{ml})\end{array}$ & $\begin{array}{l}{ }^{+} C_{50} \text { value } \\
(\mathrm{mg} / \mathrm{ml})\end{array}$ & $\begin{array}{l}\text { Chelating activity (\%) } \\
(2 \mathrm{mg} / \mathrm{ml})\end{array}$ & $\begin{array}{l}{ }^{+} \mathrm{C}_{50} \text { value } \\
(\mathrm{mg} / \mathrm{ml})\end{array}$ & $\begin{array}{l}\text { Chelating activity } \\
\text { (\%) }(2 \mathrm{mg} / \mathrm{ml})\end{array}$ & $\begin{array}{l}{ }^{+} \mathrm{C}_{50} \text { value } \\
(\mathrm{mg} / \mathrm{ml})\end{array}$ & \\
\hline NFAJ & $36.31 \pm 1.92^{\mathrm{a}}$ & $3.02 \pm 0.05^{a}$ & $49.24 \pm 1.75^{a}$ & $2.19 \pm 2.34^{a}$ & $21.76 \pm 2.35^{a}$ & $4.19 \pm 0.13^{a}$ & $1.66 \pm 0.25^{\mathrm{a}}$ \\
\hline FAJ & $86.33 \pm 0.88^{b}$ & $0.36 \pm 0.09^{b}$ & $75.04 \pm 1.73^{b}$ & $1.49 \pm 2.34^{b}$ & $37.33 \pm 1.52^{\mathrm{b}}$ & $3.07 \pm 0.11^{b}$ & $0.59 \pm 0.05^{\mathrm{b}}$ \\
\hline $\begin{array}{l}\text { Positive } \\
\text { control }\end{array}$ & $95.36 \pm 0.37^{\mathrm{c}}(\mathrm{BHT})$ & $0.02 \pm 0.01^{c}$ & $\begin{array}{l}99.43 \pm 1.28^{c} \\
\text { (Ascorbic acid) }\end{array}$ & $0.01 \pm 0.01^{c}$ & $\begin{array}{l}61.43 \pm 1.42^{\mathrm{c}} \\
\text { (Ascorbic acid) }\end{array}$ & $1.42 \pm 0.05^{c}$ & $0.12 \pm 0.01^{b}$ \\
\hline \multicolumn{8}{|c|}{$\begin{array}{l}\text { †The data-values of IC50 }(\mathrm{mg} / \mathrm{ml}) \text { means the concentration of each extract which provides } 50 \% \text { of inhibition effect in the DPPH, ABTS.+, and nitrite radical assays. } \\
\text { †tThe data-values of EC50 }(\mathrm{mg} / \mathrm{ml}) \text { means the concentration of each extract which provides } 0.5 \text { value of effective effect of absorbance in the reducing power } \\
\text { experiment. }\end{array}$} \\
\hline
\end{tabular}

Table 1: The chelating effect of DPPH, ABTS.+ ${ }^{+}$, nitrite radical with $\mathrm{IC}_{50}$ and $\mathrm{EC}_{50}$ (of reducing power) values of non-fermented (NFAJ) and fermented (FAJ) extracts of Achyranthes japonica Nakai.

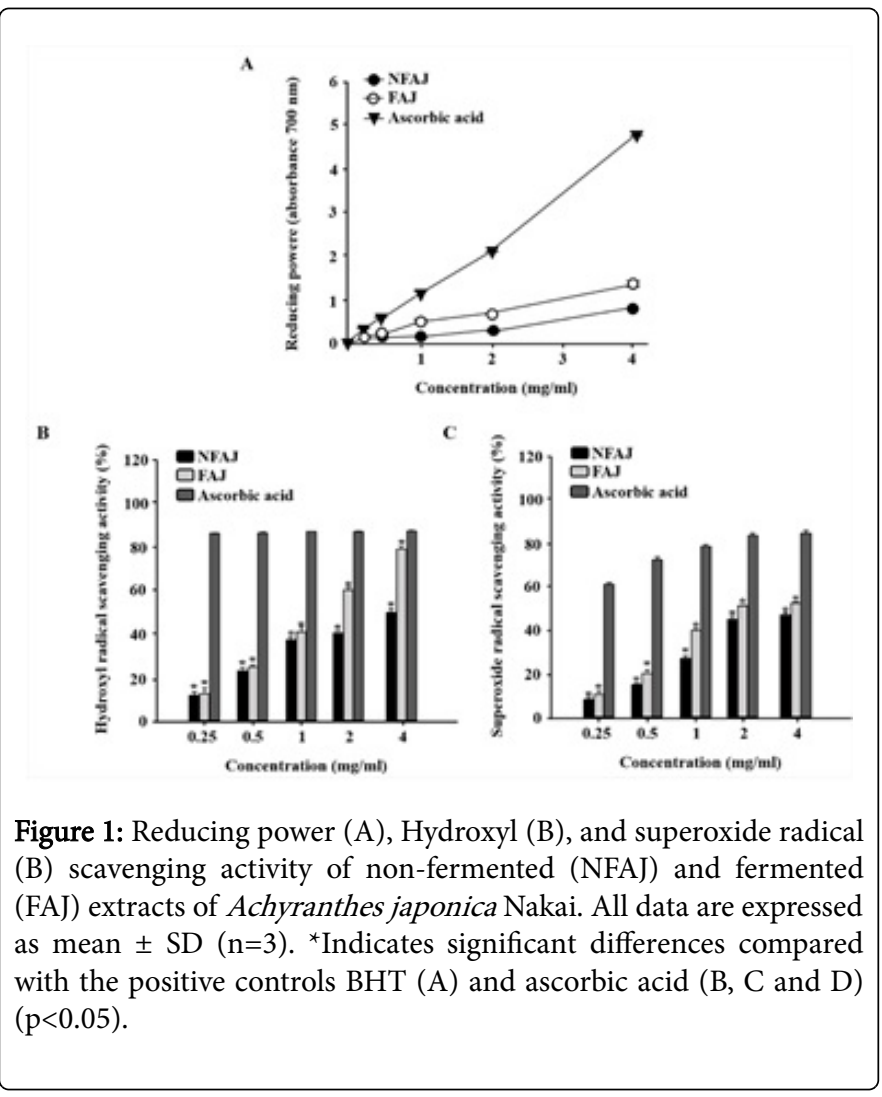

\section{Effects of $\mathrm{AJ}$ extracts on cell viability and the release of NO and $\mathrm{PGE}_{2}$}

Cytotoxic effects of the AJ extracts were measured in LPS-induced RAW 264.7 cells using MTT assay. As shown in Figure 2A, neither of the extracts produced any significant cytotoxic effects at $0.125-4 \mathrm{mg} / \mathrm{ml}$ concentration level. However, viability of the macrophage cells treated with FAJ was relatively higher than those treated with NFAJ. Macrophage cells release NO in response to host defense mechanism, the overproduction of which causes tissue damage and inflammation. NO production in the LPS-induced RAW 264.7 cells was dosedependently decreased with the treatment of NFAJ and FAJ (Figure 2B). FAJ produced stronger inhibitory effect on NO production compared with NFAJ. Prostaglandin $\mathrm{E}_{2}$ is regarded as in important mediator in the inflammation process. As shown in Figure $2 \mathrm{C}, \mathrm{PGE}_{2}$ level in RAW 264.7 cells was elevated from $182.68 \mathrm{pg} / \mathrm{ml}$ to $1,105.68$ $\mathrm{pg} / \mathrm{ml}$ after being stimulated with LPS. The elevation of PGE2 level was markedly $\left({ }^{*} \mathrm{P}<0.05\right)$ reversed by NFAJ $(753.07 \mathrm{pg} / \mathrm{ml})$ and FAJ $(602.70$ $\mathrm{pg} / \mathrm{ml}$ ) treatments at $4 \mathrm{mg} / \mathrm{ml}$.

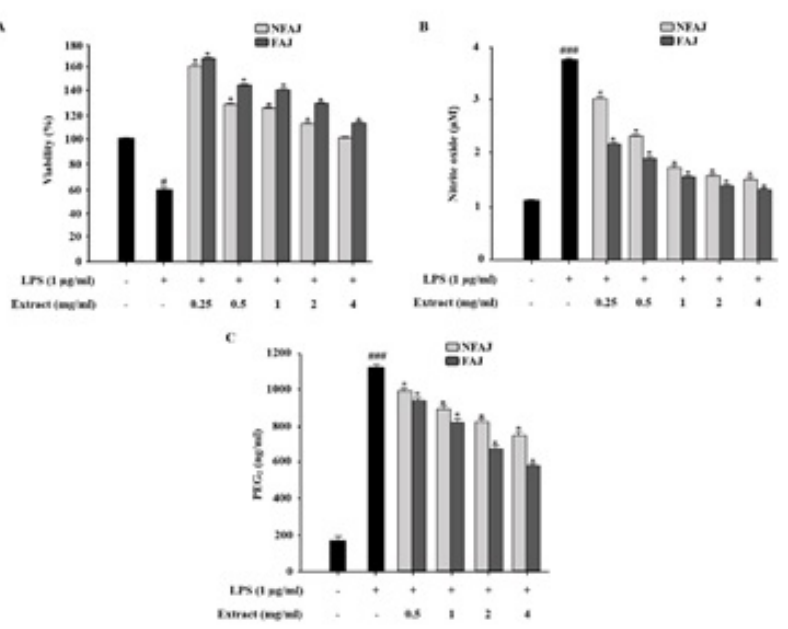

Figure 2: Effects of the fermented extract of Achyranthes japonica Nakai (FAJ) on cell viability (A), nitric oxide (NO) (B) and prostaglandin $\mathrm{E}_{2}\left(\mathrm{PGE}_{2}\right)$ production $(\mathrm{C})$ in LPS-induced RAW 264.7 cells. All data are expressed as mean \pm S.D $(n=3)$. ${ }^{\# \# \#} \mathrm{P}<0.001$ compared with the control group; ${ }^{*} \mathrm{P}<0.05$ compared with the LPStreated group. 


\section{Effects of AJ extracts on pro-inflammatory cytokine production}

To investigate the inhibitory activities of $\mathrm{AJ}$ extracts on the production of pro-inflammatory cytokines, the expression of TNF- $\alpha$ was measured (Figure 3). TNF- $\alpha$ expression was remarkably increased with LPS stimulation $\left({ }^{\# \# \#} \mathrm{P}<0.001\right)$ compared with the normal cells (non LPS). The overexpression of TNF- $\alpha$ was significantly reduced by FAJ treatment $\left.{ }^{* * *} \mathrm{P}<0.05\right)$ with different concentrations $(1,2$ and $4 \mathrm{mg} /$ $\mathrm{ml}$ ), whereas NFAJ extract did not produce any noticeable effect on TNF- $\alpha$ expression.
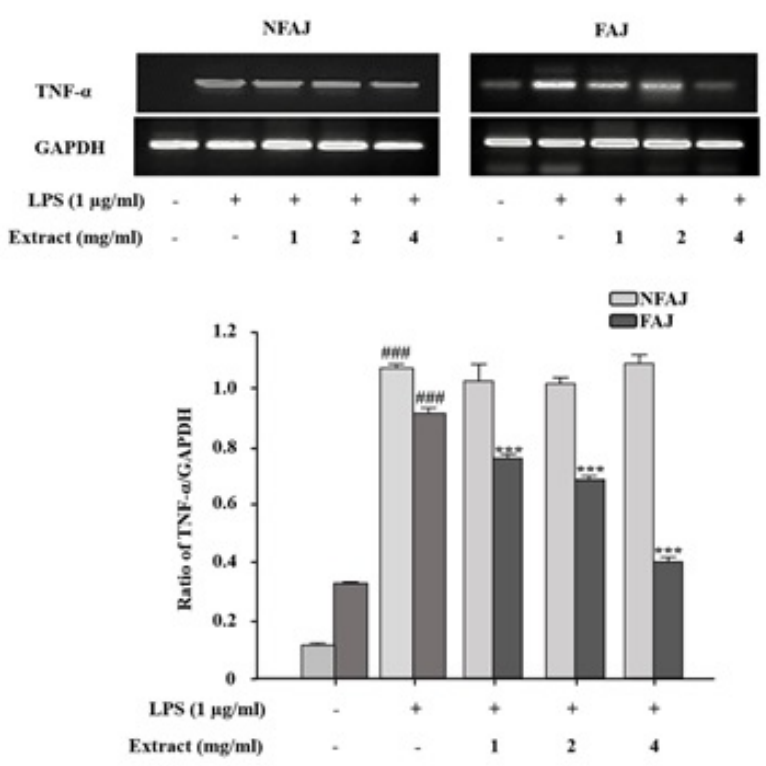

Figure 3: Effects of fermented extract of Achyranthes japonica Nakai (FAJ) on the mRNA levels of TNF- $a$ in LPS-induced RAW 264.7 cells. All data were expressed as means \pm S.D $(n=3)$. The obtained ratio of TNF- $\alpha$ /GAPDH was quantified by using ImageJ software. ${ }^{\# \# \#} \mathrm{P}<0.001$ compared with the control group; ${ }^{* * *} \mathrm{P}<0.001$ compared with the LPS-treated group.

\section{Effects of AJ extracts on the LPS-induced activation of MAPKs}

It is generally accepted that MAPKs are the key signaling pathways that regulate cellular processes, including the release of proinflammatory cytokines under chronic inflammation [11]. The expression of MAPKs (p38, ERK, and JNK) in LPS-induced RAW 264.7 cells were analysed by western blotting. These inflammatory mediators were highly activated with LPS stimulation (Figure 4A-4C). The FAJ extract reduced the expression of pp38 at different concentrations (1,2, and $4 \mathrm{mg} / \mathrm{ml}$; Figure $4 \mathrm{~A}$ ). The overexpression of pERK, which is linked to the increase of TNF- $\alpha$ production was substantially attenuated by FAJ treatment (Figure 4B). However, FAJ did not have any significant effect on pJNK phosphorylation (Figure 4 C).

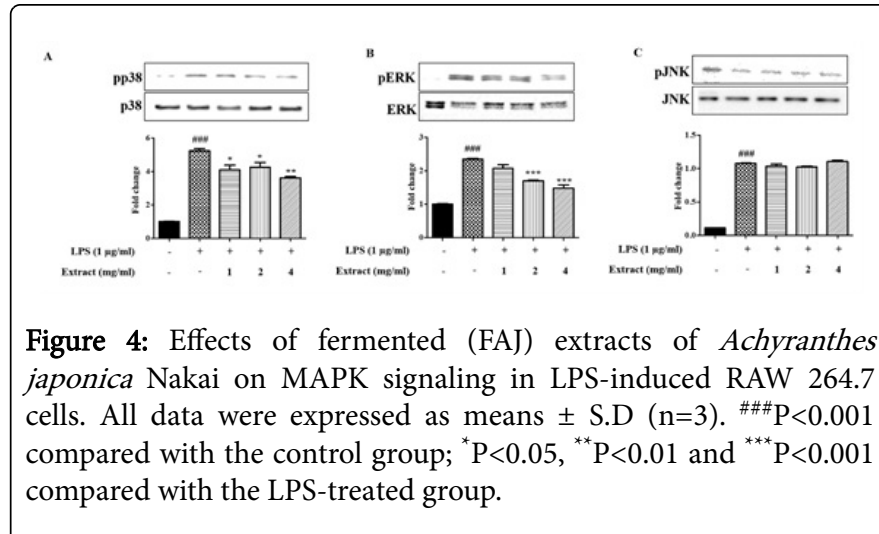

\section{Discussion}

The anti-inflammatory effects of fermented AJ have been mentioned previously [16]. However, the earlier reports did not elucidate the molecular mechanisms, such as MAPK signaling, which directly regulate the inflammation process. This study found that the fermentation of $\mathrm{AJ}$ extracts markedly improved its antioxidant and anti-inflammatory functions, with regards to the scavenging of free radicals and the inhibition of pro-inflammatory cytokines and MAPK pathways.

Polyphenols are the main antioxidant compounds found in plants [29]. Fermentation of the AJ extracts resulted in the increase of total phenolic and flavonoid contents were, indicating that the major polyphenolic compounds, such as 2-hydroxyecdysone and saponin in the extract might increase during the fermentation process. This result is in accordance with a previous report, where the content of 2hydroxyecdysone increased in AJ after fermentation [16].

The synthetic free radicals, such as DPPH and $\mathrm{ABTS}^{+}$are widely used tools to determine the hydrogen donation $\left(\mathrm{H}^{+}\right)$capacity of antioxidants to toxic free radicals in cells [30]. Nitrite is a highly reactive substance, the ionic form of which increases the risk of chronic inflammatory diseases through cell damage and mutagenesis [31]. FAJ, in this study, demonstrated strong free radical scavenging activity against $\mathrm{DPPH}, \mathrm{ABTS}^{+}$, and nitrite, which can be attributed to its high polyphenol content. Perera et al. (2016) also reported that the amounts of polyphenols and the inhibition of free radical scavenging activity of a natural extract were strongly correlated [32].

Hydroxyl $(\bullet \mathrm{HO})$ radicals can cause DNA damage and can induce mutagenesis, cytotoxicity, and lipid peroxidation etc. [33]. It has been reported that $\mathrm{O}^{2-}$ causes aging through oxidative stress [34]. Both extracts showed powerful scavenging activities against $\mathrm{OH}$ and $\mathrm{O} 2$ radicals. And the stronger free radical scavenging activity of FAJ can be attributed to the enrichment of phenolic content in AJ through the fermentation process.

Macrophages play essential roles in inflammation by producing inflammatory cytokines, mediators, and growth factors [35]. The overproduction of NO and PGE2 by macrophage cells is one of the key factors involved in the development of inflammatory diseases [36]. This study found that FAJ was more efficient than NFAJ in inhibiting $\mathrm{NO}$ and $\mathrm{PGE}_{2}$ in LPS-induced macrophage cells. An earlier study also suggested that fermented AJ showed very high level of inhibitory effects against NO and PGE2 in LPS-induced macrophage cells [16]. TNF- $\alpha$ is a pro-inflammatory cytokine, mainly produced by the 
nuclear translocation of NF- $\kappa \mathrm{B}$ in chronic diseases [9]. FAJ suppressed the mRNA level of TNF- $\alpha$ in LPS-stimulated macrophage cells in a dose-dependent manner (Figure 3). This result is similar to an animal study, where fermented AJ substantially inhibited the levels of TNF- $\alpha$, IL-4 in rats [16].

Furthermore, FAJ strongly inhibited the activation of MAPK pathways in LPS-induced macrophage cells. It is well-known that the activation of MAPKs, such as pp38, pERK, and pJNK is associated with chronic inflammation [37]. Previous studies have shown that MAPKs accelerated the release and activation of pro-inflammatory cytokines and mediators [38,39]. Therefore, these signaling pathways are important targets for the development of therapeutic agents against inflammation. In this study, FAJ markedly decreased the protein levels of pp38 and pERK macrophage cells, indicating FAJ's potential as antiinflammatory agent (Figure 4).

\section{Conclusion}

Fermentation increased the total phenolic and flavonoid contents in the AJ extract. The increase of polyphenols in FAJ resulted in stronger antioxidative and anti-inflammatory functions. The major effect of fermentation of $\mathrm{AJ}$ was its strong inhibitory activity against MAPK pathway, which regulates the production and activation of inflammatory cytokines and mediators. Moreover, FAJ has shown substantial effect in decreasing the production of $\mathrm{NO}$ and the expression of TNF- $\alpha$. Therefore, FAJ could be a suitable candidate as a biomedicine for oxidative stress and chronic inflammation. However, further studies are needed to determine the compositional changes in AJ during fermentation and to corroborate current findings.

\section{Conflicts of interest}

The authors declare no conflict of interest.

\section{Acknowledgements}

This work was supported by Korea Institute of Planning and Evaluation for Technology in Food, Agriculture, Forestry (IPET) through High Value-added Food Technology Development Program, funded by Ministry of Agriculture, Food and Rural Affairs (MAFRA) (117073-3).

\section{References}

1. Bellot GL, Liu D, Pervaiz S (2013) ROS, autophagy, mitochondria and cancer: Ras, the hidden master? Mitochondrion 13: 155-162.

2. Poprac P, Jomova K, Simunkova M, Kollar V, Rhodes CJ, et al. (2017) Targeting free radicals in oxidative stress-related human diseases. Trends Pharmacol Sci 38: 592-607.

3. Zhang H, Tsao R (2016) Dietary polyphenols, oxidative stress and antioxidant and anti-inflammatory effects. Curr Opin Food Sci 8: 33-42.

4. Raikos V (2017) Natural antioxidants for food applications: challenges and recent developments. EC Nutrition 2: 33-34.

5. Reyes-Gordillo K, Shah R, Muriel P (2017) Oxidative stress and inflammation in hepatic diseases: current and future therapy. Oxid Med Cell Longev 17: 314-673.

6. Hamidzadeh K, Christensen SM, Dalby E, Chandrasekaran P, Mosser DM (2017) Macrophages and the recovery from acute and chronic inflammation. Annu Rev Physiol 79ss: 567-592.

7. Yang EJ, Hyun KH, Kim H, Kim MJ, Lee NH, et al. (2016) Acanthopanax koreanum roots inhibit the expression of pro-inflammatory cytokines, inducible nitric oxide synthase, and cyclooxygenase-2 in RAW 264.7 macrophages. Orient J Chem 32: 29-35.

8. Serhan CN (2017) Treating inflammation and infection in the 21st century: New hints from decoding resolution mediators and mechanisms. FASEB Journal 31: 1273-1288.

9. Xiao M, Zhu T, Zhang W, Wang T, Shen YC, et al. (2014) Emodin ameliorates LPS-induced acute lung injury, involving the inactivation of NF- $\kappa B$ in mice. Int J Mol Sci, 15: 19355-19368.

10. Jang HL, El-Gamal MI, Choi HE, Choi HY, Lee KT, et al. (2014) Synthesis of tricyclic fused coumarin sulfonates and their inhibitory effects on LPSinduced nitric oxide and PGE2 productions in RAW 264.7 macrophages. Bioorganic Med Chem Lett 24: 571-575.

11. Moens U, Kostenko S, Sveinbjørnsson B (2013) The role of mitogenactivated protein kinase-activated protein kinases (MAPKAPKs) in inflammation. Genes 4: 101-133.

12. Li Y, Wang $\mathrm{Y}, \mathrm{Wu} \mathrm{Y}$, Wang B, Chen $\mathrm{X}$, et al. (2017) Echinacea pupurea extracts promote murine dendritic cell maturation by activation of $\mathrm{JNK}$, p38 MAPK and NF-??B pathways. Dev Comp Immunol 73: 21-26.

13. Lambert WS, Carlson BJ, Formichella CR, Sappington RM, Ahlem C, et al. (2017) Oral delivery of a synthetic sterol reduces axonopathy and inflammation in a rodent model of glaucoma. Front Neurosci 11: 45.

14. Yaribeygi H, Panahi Y, Sahraei H, Johnston TP (2017) Review article: The impact of stress on body function: a review. EXCLI J 16: 1057-1072.

15. Hong IH, Choi JY, Kim AY, Lee EM, Kim JH, et al. (2016) Antirheumatoid arthritic effect of fermented Adlay and Achyranthes japonica Nakai on collagen-induced arthritis in mice. Food Agric Immunol 28: 14-26.

16. Lee SG, Lee EJ, Park WD, Kim JB, Kim EO, et al. (2012) Antiinflammatory and anti-osteoarthritis effects of fermented Achyranthes japonica Nakai. J Ethnopharmacol 142: 634-641.

17. Liu M, Dai Y, Yao X, Li Y, Luo Y, et al. (2008) Anti-rheumatoid arthritic effect of madecassoside on type II collagen-induced arthritis in mice. Int Immuno pharmacol 8: 1561-1566.

18. Koyama M, Ogasawara Y, Endou K, Akano H, Nakajima T, et al. (2017) Fermentation-induced changes in the concentrations of organic acids, amino acids, sugars, and minerals and superoxide dismutase-like activity in tomato vinegar. Int J Food Prop 20: 888-898.

19. Huang Q, Zhang H, Xue D (2017) Enhancement of antioxidant activity of Radix Puerariae and red yeast rice by mixed fermentation with Monascus purpureus. Food Chem 226: 89-94.

20. Wang GH, Chen CY, Lin CP, Huang CL, Lin CH, et al. (2016) Tyrosinase inhibitory and antioxidant activities of three Bifidobacterium bifidumfermented herb extracts. Ind Crops Prod 89: 376-382.

21. Shukla S, Park J, Kim DH, Hong SY, Lee JS, et al. (2016) Total phenolic content, antioxidant, tyrosinase and a-glucosidase inhibitory activities of water soluble extracts of noble starter culture Doenjang, a Korean fermented soybean sauce variety. Food Control 59: 854-861.

22. Hakiman M, Syed MA, Syahidal A, Maziah M (2012) Total antioxidant, polyphenol, phenolic acid, and flavonoid content in Ficus deltoidea varieties. J Med Plants Res 6: 4776-3784.

23. Samad NB, Debnath T, Jin HL, Lee BR, Park PJ, et al. (2011) Antioxidant activity of Benincasa hispida seed. J Food Biochem 37: 388-395.

24. Moo-Huchin VM, Moo-Huchin MI, Estrada-León RJ, Cuevas-Glory L, Estrada-Mota IA, et al. (2015) Antioxidant compounds, antioxidant activity and phenolic content in peel from three tropical fruits from Yucatan, Mexico. Food Chem 166: 17-22.

25. Cui JL, Guo TT, Ren ZX, Zhang NS, Wang ML (2015) Diversity and antioxidant activity of culturable endophytic fungi from alpine plants of Rhodiola crenulata, R. angusta, and R. sachalinensis. PLoS One 10: e0118204.

26. Baba SA, Malik SA (2015) Determination of total phenolic and flavonoid content, antimicrobial and antioxidant activity of a root extract of Arisaema jacquemontii Blume. J Taibah Univ Sci 9: 449-454. 
Citation: $\quad$ Al Mijan M, Hyun Park S, Min Lee Y and Ou Lim B* (2018) Evaluation of The Antioxidant and Anti-Inflammatory Potential of Fermented Achyranthes japonica Nakai Extract. Nat Prod Chem Res 6: 337. doi:10.4172/2329-6836.1000337

Page 7 of 7

27. Debnath T, Park SR, Kim DH, Jo JE, Lim BO (2013) Antioxidant and anti-inflammatory activity of Polygonatum sibiricum rhizome extracts. Asian Pacific J Trop Dis 3: 308-313.

28. Kim KO, Ku CS, Kim MJ, Park YJ, Ryu HW, et al. (2015) Phytoecdysones from the roots of Achyranthes japonica Nakai and their anti-atopy activity. J Appl Biol Chem 58: 13-19.

29. Shahidi F, Ambigaipalan P (2015) Phenolics and polyphenolics in foods, beverages and spices: Antioxidant activity and health effects-a review. J Funct Foods 18: 820-897.

30. Apak R, Özyürek M, Güçlü K, Çapanołlu E (2016) Antioxidant activity/ capacity measurement. 2. hydrogen atom transfer (HAT)-based, mixedmode (electron transfer (ET)/HAT), and lipid peroxidation assays. J Agric Food Chem 64: 1028-1045.

31. Gassara F, Kouassi AP, Brar SK, Belkacemi K (2016) Green alternatives to nitrates and nitrites in meat-based products-a review. Crit Rev Food Sci Nutr 56: 2133-2148.

32. Perera D, Soysa P, Wijeratne S (2016) Polyphenols contribute to the antioxidant and antiproliferative activity of Phyllanthus debilis plant invitro. BMC Complement Altern Med 16: 339.

33. Liu GY, Sun YZ, Zhou N, Du XM, Yang J, et al. (2016) 3,3'-OH curcumin causes apoptosis in HepG2 cells through ROS-mediated pathway. Eur J Med Chem 112: 157-163.
34. Xu D, Liu D, Wang B, Chen C, Chen Z, et al. (2015) In situ OH generation from $\mathrm{O} 2$ - and $\mathrm{H} 2 \mathrm{O} 2$ plays a critical role in plasma-induced cell death. PLoS One 10: e0128205.

35. Wynn TA, Chawla A, Pollard JW (2013) Macrophage biology in development, homeostasis and disease. Nature 496: 445-455.

36. Ghasemi H (2018) Roles of IL-6 in Ocular Inflammation: A Review. Ocul Immunol Inflamm 26: 37-50.

37. Lanna A, Gomes DCO, Muller-Durovic B, McDonnell T, Escors D, et al (2017) A sestrin-dependent Erk-Jnk-p38 MAPK activation complex inhibits immunity during aging. Nat Immunol 18: 354-363.

38. Jeong YH, Oh YC, Cho WK, Lee B, Ma JY (2016) Anti-inflammatory effects of Melandrii herba ethanol extract via inhibition of NF- $\kappa B$ and MAPK signaling pathways and induction of HO-1 in RAW 264.7 cells and mouse primary macrophages. Molecules 21: 818.

39. Limtrakul P, Yodkeeree S, Pitchakarn P, Punfa W (2016) Antiinflammatory effects of proanthocyanidin-rich red rice extract via suppression of MAPK, AP-1 and NF- $\kappa$ B pathways in Raw 264.7 macrophages. Nutr Res Pract 10: 251-258. 